\title{
The Meeting of Waters, a possible shelter of evolutionary significant units for Amazonian fish
}

\author{
Alba Ardura • Vanessa Gomes • Ana R. Linde • \\ Josino C. Moreira • Jose L. Horreo • \\ Eva Garcia-Vazquez
}

Received: 27 November 2012/ Accepted: 30 May 2013/Published online: 13 June 2013

(C) Springer Science+Business Media Dordrecht 2013

\begin{abstract}
Identification of priority conservation areas is crucial for safeguarding freshwater ecosystems. Occurrence of unique populations and/or evolutionary significant units for key species is one of the most frequent reasons for protecting a region or location. In this study we have studied two of the most important fisheries resources of the Amazon basin, Curimata and Tambaqui, from different areas, in order to identify common zones of special diversity. Employing the Barcoding cytochrome oxidase I gene as a genetic tool, we have detected a clear differentiation of the populations inhabiting the Meeting of Waters and the rest of the basin for both species. This area corresponds to the confluence of the Solimões and the Negro rivers, of different physicochemical water characteristics, at the Brazilian city of Manaus in central Amazonas. The Meeting of Waters area (near Manaus) could be recommended as a potential area subject of special management, given its apparent role as a shelter for evolutionary significant units.
\end{abstract}

Keywords Amazon river - Meeting of Waters · Mitochondrial DNA · Prochilodus nigricans · Colossoma macropomum . Population structure

Alba Ardura and Vanessa Gomes contributed equally to this study.

A. Ardura $(\bowtie) \cdot$ J. L. Horreo · E. Garcia-Vazquez Departamento de Biologia Funcional, Universidad de Oviedo, C/Julian Claveria s/n, 33006 Oviedo, Spain

e-mail: alarguti@hotmail.com

V. Gomes · A. R. Linde · J. C. Moreira Laboratorio de Toxicologia, Escola Nacional de Saúde Pública, Fundaçao Oswaldo Cruz, Rio de Janeiro, Brazil

\section{Introduction}

The Amazon exhibits all the principle features associated with aquatic species richness globally (Albert and Reis 2011). It is the greatest interconnected fluvial system on the planet, extending over more than 7 million $\mathrm{km}^{2}$. The Amazon river alone carries about a sixth of the all world's flowing freshwater. Its tropical location, straddling the equator, means it receives high levels of solar radiation and precipitation, and the region is largely covered by humid lowland rainforests. From a purely ecological perspective, therefore, Amazonia as it is today appears to be an excellent environment for fishes (Albert and Crampton 2010).

The main river Amazon originates from the confluence of the Solimões (the upper Amazon tributary) and the Negro (=black) rivers at the Brazilian city of Manaus in central Amazonas (Fig. 1). At the river conjunction, the muddy, tan-colored waters of the river Solimões meet the "black" water of the river Negro. For $6 \mathrm{~km}$ downstream the two types of water run in parallel without mixing. This phenomenon, called the Meeting of Waters, is due to differences in temperature, speed and water density. The river Negro flows at near $2 \mathrm{~km} / \mathrm{h}$ at a temperature of $22{ }^{\circ} \mathrm{C}$, while the river Solimões flows among $4-6 \mathrm{~km} / \mathrm{h}$ and at $28{ }^{\circ} \mathrm{C}$. The water in the river Negro is acidic, with $\mathrm{pH}$ around 4.5, whereas the river Solimões water is neutral, around $\mathrm{pH}=7$. The sudden change in $\mathrm{pH}$ causes precipitates of carbon-based macromolecules and form a mineralrich sludge that supports detritivorous fishes and planktonic growth (Schmidt 1976). Besides being a very beautiful tourist attraction, this region is of special interest for biodiversity since it is the border of clearly distinct environments. Each tributary carries different aquatic flora and fauna adapted to its particular conditions, and the joining point, as other friction or contact zones, exhibits special 


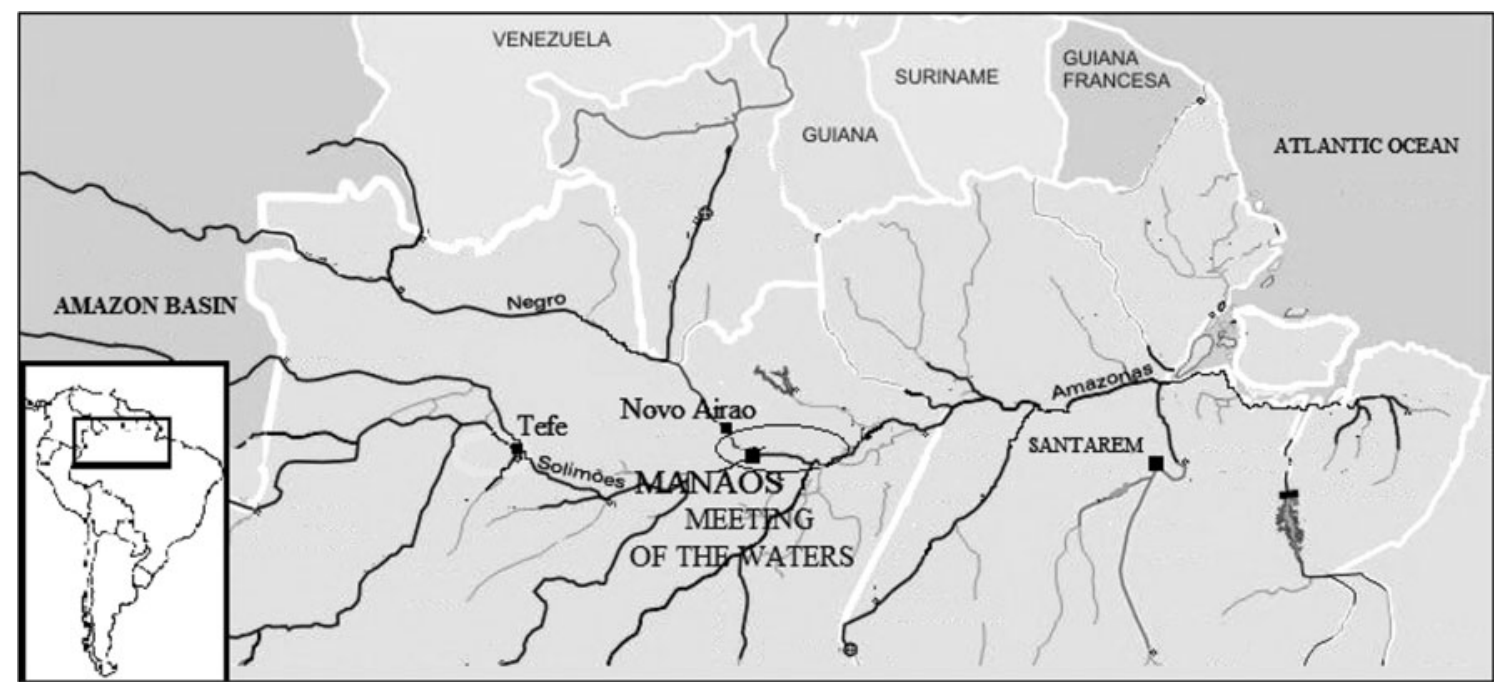

Fig. 1 Sampling sites in the Amazon Basin (black squares): Novo Airao in the Black River, Tefe in the Solimões River, Manaus in the confluence or Meeting of Waters, and Santarem downstream.

habitat conditions that may be highly instable but also a melting pot for diversity. For example, the area is highly attractive for river dolphins (Martin et al. 2004). It could theoretically contain populations adapted to such special and instable conditions that would represent unique genetic pools, may be evolutionary significant units. Significant evolutionary units, that is, biological units with particular genetic identity, are a priority for conservation and management purposes (Moritz 1994, Waples 1995).

Unique populations are generally isolated populations. The degree of isolation of a population depends on physical barriers and on the dispersal capacity of the organisms (Reeves et al. 1995; Kinlan and Gaines 2003), as well as on historical processes. Geographical and physicochemical factors like $\mathrm{pH}$ and temperature or biogeography barriers can shape population structure of freshwater organisms, contributing to isolate stocks which may accumulate singular genetic diversity or variants absent in the rest of the species distribution (Hughes et al. 2009). The Meeting of the Waters exhibits a priori such a condition of differential biogeography that could host evolutionary significant units.

To analyze the importance of the Meeting of Waters area (near Manaus) as a special habitat or shelter for unique populations, that is, to know if it promotes any faunal barrier, two of the most important fish resources of the Amazonian were sampled from this area and outside places along the two main Amazon branches: Prochilodus nigricans (Curimata) and Colossoma macropomum (Tambaqui).

For Amazonian continental fisheries, characins are the preferred group with $43 \%$ catch and within this group Tambaqui and Curimata are the main species of commercial interest (Quintero-Pinto 2003). These two species are considered of similar trophic level, but exhibit different
Distances between them: Novo Airao-Manaus $\rightarrow 199 \mathrm{~km}$, TefeManaus $\rightarrow 356 \mathrm{~km}$, Santarem-Manaus $\rightarrow 596 \mathrm{~km}$

habitat preferences and migratory behavior (Table 1). $\mathrm{Cu}-$ rimata (Prochilodus nigricans) prefers slow waters with detritus in the bottom and neutral $\mathrm{pH}$ around 6.7-7. It is iliophagus, feeding on organic detritus, periphyton, zooplankton and small food items. It forms shoals and undertake long migrations (Silva and Sterwart 2006; Sivasundar et al. 2008). On the other hand, Tambaqui ( $\mathrm{Col}$ ossoma macropomum) is a frugivorous species. Juveniles prefer black waters of flooded forests until their sexual maturity, and adults remain there during the first 5 months of flooding and feed on fruits and seeds (Ziburski 1990), since most of the tree and bush species fruit during the high-water period (Ziburski 1990; Colonnello 1991). They display upstream migrations during the periods of low flow (Araújo-Lima and Ruffino 2004). This species is very resistant to diseases and can live in poorly mineralized water with a $\mathrm{pH}$ as low as five.

Population structuring of these species seems to be shallow. Previous genetic studies suggest that Tambaqui constitutes a panmictic population in the main channel of the Amazon basin (Santos et al. 2007; Farias et al. 2010). For Curimatá, genetic differentiation was found only between distant tributaries; intense migration along the main river Amazon would favor the development of a large population in demographic expansion for the last centuries (Sivasundar et al. 2008).

To our knowledge, the individuals inhabiting near the Meeting of Waters have not been specifically considered as a potentially different population unit, since no previous studies have been published about the ecological importance of aquatic organisms from this area. Thus here we have investigated the level of population differentiation between the rivers confluence and other upstream and 
Table 1 Catch in tons (\% over total catch) from each species in the Amazonas (Tefe, Novo Airao and Manaus) and Pará (Santarem) states

\begin{tabular}{llrr}
\hline Commercial name & Scientific name & Catch $(\%)$ & Pará \\
\cline { 3 - 4 } & & Amazonas & $2,342.5(11.5 \%)$ \\
\hline Curimata & Prochilodus nigricans & $6,934(3.8 \%)$ & $1,255.5(4.4 \%)$ \\
Tambaqui & Colossoma macropomum & $2,664.5(2.0 \%)$ & $1,25.5$ \\
\hline
\end{tabular}

downstream areas, based on variation at the Barcoding COI mitochondrial sequence (Ward et al. 2005).

\section{Materials and methods}

Samples collection

Curimata and Tambaqui samples were obtained from different points along the Amazon basin. Since the Amazon river is very long, four points from its basin were chosen along the basin: the two tributaries that form the Amazon river (river Negro with black water and river Solimões with white water), the confluence and a point downstream. Due to the difficulty of sampling the river, local markets are a good option, since local fishermen use artisanal fisheries. They do not have sophisticated gear and freezers in their small boats, therefore they fish in a nearby area and return quickly to the market for selling fresh catch. This reasonably ensures that the fish come from the area that we want to sample. Upstream the Meeting of Waters, Novo Airao was the location of reference for upstream river Negro samples, and Tefe was the upstream river Solimões sampling site (Fig. 1). Samples from the Meeting of Waters were obtained in Manaus. Finally, the location of Santarem was chosen as a downstream reference (Fig. 1). A total of 114 and 76 samples of adult Curimata and Tambaqui respectively (Table 2) were obtained from the above cited sampling points, directly purchased to fishermen in local harbors and markets in August 2009.

DNA extraction and genetic analysis

Total DNA was extracted from a small piece of alcoholpreserved tissue following the standard protocol of
Estoup et al. (1996), using Chelex ${ }^{\circledR}$ resin (Bio-Rad Laboratories). The tissue is introduced in an Eppendorf tube with $500 \mathrm{ml}$ of Chelex resin $(10 \%)$ and $7 \mu \mathrm{l}$ of Proteinase $\mathrm{K}(20 \mathrm{mg} / \mathrm{ml})$. It is incubated at $55^{\circ} \mathrm{C}$ for $90 \mathrm{~min}$. The DNA is dissolved in the aqueous solution. Finally, it is introduced in an oven at $100{ }^{\circ} \mathrm{C}$ during $20 \mathrm{~min}$ for inactivating the enzyme. The tube is stored at $4{ }^{\circ} \mathrm{C}$ or frozen at $-20{ }^{\circ} \mathrm{C}$ for long-time preservation. The samples of Whitewater river were collected in FTA cards $\left(\right.$ Whatman ${ }^{\circledR}$ ), the DNA was extracted following manufacturer's instructions.

The Barcoding fragment of the mitochondrial COI gene was amplified by polymerase chain reaction (PCR), employing the primers described by Ward et al. (2005). This gene could be representative of the whole mitochondrial genome for this first approach (Horreo 2012). The amplification reaction was performed in a total volume of $40 \mu \mathrm{l}$, including Promega (Madison, WI) Buffer $1 \times, 2.5 \mathrm{mM}$ $\mathrm{MgCl} 2,0.25 \mathrm{mM}$ dNTPs, 20 pmol of each primer, $20 \mathrm{ng}$ of template DNA, and 1 U of DNA Taq polymerase (Promega). The thermocycler conditions for the amplification were: an initial denaturing step at $95{ }^{\circ} \mathrm{C}$ for $5 \mathrm{~min}$, then 35 cycles of denaturation at $95{ }^{\circ} \mathrm{C}$ for $20 \mathrm{~s}$, annealing at $56{ }^{\circ} \mathrm{C}$ for $20 \mathrm{~s}$ and extension at $72{ }^{\circ} \mathrm{C}$ for $30 \mathrm{~s}$, and one final extension at $72{ }^{\circ} \mathrm{C}$ for $20 \mathrm{~min}$.

PCR products were visualized in $2 \%$ agarose gels with $3 \mu \mathrm{l}$ of $10 \mathrm{mg} / \mathrm{ml}$ ethidium bromide. Stained bands were excised from the gel, and DNA was purified with an Eppendorf PerfectPrep Gel CleanUp ${ }^{\circledR}$ kit prior-sequencing. After that, amplified and purified products were precipitated using standard 2-propanol precipitation and resuspended in formamide. Sequencing was performed in an ABI PRISM 3130 genetic analyzer (Applied Biosystems) with BigDye 3.1 terminator system, at the sequencing unit of the University of Oviedo (Spain).

Table 2 Variation at the COI gene sequence found for Curimata and Tambaqui at the sampling locations considered

\begin{tabular}{|c|c|c|c|c|c|c|c|c|c|c|c|c|c|c|c|c|c|c|c|c|}
\hline & \multicolumn{5}{|c|}{ Upstream Blackwater } & \multicolumn{5}{|c|}{ Upstream Whitewater } & \multicolumn{5}{|c|}{ Meeting of Waters } & \multicolumn{5}{|c|}{ Downstream } \\
\hline & $n$ & $\mathrm{Nh}$ & $\mathrm{pH}$ & $\mathrm{Hd}$ & $\pi$ & $n$ & $\mathrm{Nh}$ & $\mathrm{pH}$ & $\mathrm{Hd}$ & $\pi$ & $n$ & $\mathrm{Nh}$ & $\mathrm{pH}$ & $\mathrm{Hd}$ & $\pi$ & $n$ & $\mathrm{Nh}$ & $\mathrm{pH}$ & $\mathrm{Hd}$ & $\pi$ \\
\hline Curimatá & 32 & 4 & 1 & 0.591 & 0.00115 & 20 & 3 & 0 & 0.563 & 0.00102 & 25 & 2 & 0 & 0.080 & 0.00013 & 37 & 10 & 7 & 0.724 & 0.00164 \\
\hline Tambaqui & 3 & 2 & 0 & 0.667 & 0.00106 & 17 & 6 & 1 & 0.794 & 0.00220 & 24 & 4 & 1 & 0.482 & 0.00238 & 32 & 10 & 4 & 0.859 & 0.00290 \\
\hline
\end{tabular}

$n, \mathrm{Nh}, \mathrm{PH}, \mathrm{Hd}$ and $\pi$ : number of samples analyzed for each species at each sampling point along the Amazon basin, number of haplotypes, number of private haplotypes, haplotype diversity and nucleotidic diversity respectively 
Sequence edition

Sequences were visualized and edited employing the BioEdit sequence alignment editor software (Hall 1999). They were aligned with the ClustalW application (Thompson et al. 1994) included in BioEdit.

\section{DNA data analysis}

Genetic differentiation between populations was measured with $\phi_{\mathrm{ST}}$ statistics, which is based on differences in nucleotide diversity between haplotypes. The program Arlequin (Excoffier et al. 2005) was employed for estimates of $\phi_{\mathrm{ST}}$ values and their statistical significance between samples pairs, i.e. the significance of population differentiation, with 10,000 permutations for significance.

Deviation from equilibrium expectations were tested with Tajima's D (1989) and Fu's $F_{\mathrm{s}}$ (Fu 1997) neutrality tests based on an infinite-site model without recombination, searching for signals of population expansions in the analyses lineages. On the other hand, mismatch distributions ( $r$ ) (Harpending 1994) and the test $R_{2}$ (Ramos-Onsins and Rozas 2002) were analyzed, comparing the observed distributions with those expected under a model of population expansion. The program Arlequin was employed for these tests (Excoffier et al. 2005).

A median-joining network (Bandelt et al. 1999) was constructed to represent visually the intra-specific genealogy of the dataset of haplotypes and their relative frequencies in the sampled populations using the software network 4.5 (available at http://www.fluxus-technology. com), with default settings.

The number of migrants per generation $\left(N_{\mathrm{m}}\right)$ between sampling points were calculated with the program MIGRATE 3.2.16 (Beerli and Palczewski 2010) with the following settings: three concurrent chains (replicates) with Bayesian inference strategy, 5,000,000 recorded steps (with an increment of 100 every step), four chains with a static heating scheme and a swapping interval of one. Analyses were repeated in three runs to confirm the chains convergence.

In order to detect genetic breaks or limits between populations, we used the Monmonier's (1973) maximum difference algorithm implemented in the software Barrier 2.2 (Manni et al. 2004). This method identifies zones of sharp changes (genetic barriers) based on genetic and geographical distance matrices.

\section{Results}

Variation at COI: DNA polymorphism

The length of the COI sequence obtained by PCR with the employed primers was 608 nucleotides for Curimata and 629 nucleotides for Tambaqui. Ten variable sites were found which corresponded to 11 haplotypes (GenBank Accession numbers JN032683-JN032693) in Curimata and eight variable sites were found, corresponding to 12 different haplotypes (GenBank Accession numbers JN032694-JN032704 and FJ418767) in Tambaqui. In both cases, the Meeting of Waters sample exhibited lower haplotype diversity than the rest of the river areas (the blackwater sample should be taken with caution due to its small size), but the nucleotidic diversity was similar.

\section{Demographic estimators}

Concerning demographic estimators, these indicators were contradictory for the two species (Table 3 ). In the case of Curimata, the population inhabiting the Meeting of Waters and downstream exhibited significantly negative Fu's and $\mathrm{D}$ tests, and based on mismatch analyses the sudden expansion model of population growth could not be rejected (non-significant raggedness and low $R_{2}$ values). All these indicators together support population expansion in these two areas, since in upstream tributaries there were no significant indices of population expansion. For Tambaqui, however, Fu's test was significant for downstream and whitewater samples, whereas Tajimas's test was not statistically significant in any case. Mismatch analyses did not allow to rejecting a sudden expansion model of population growth in any case (non-significant raggedness values). The lowest $R_{2}$ value corresponded to downstream samples but was not very different from those obtained for whitewater and the Meeting of Water samples (Table 3).

These tests need to be considered with caution, only like a first approximation, due to limited number of haplotypes found in some samples.

\section{Differentiation between populations along the basin}

Haplotype networks were different in both cases. For Curimata (Fig. 2 left), it yielded a clear double-star shape with two major haplotypes, $\mathrm{H} 1$ and $\mathrm{H} 2$, which could be considered two lineages and occurred in all sampling points with different frequencies. The rest of the haplotypes were derived from them and most of them were unique downstream, with the exceptions of $\mathrm{H} 3$ (also present in the two upstream tributaries) and H11 (exclusively found in the blackwater location). In the case of Tambaqui, it exhibited a complex shape with three more frequent haplotypes, from which all the rest derived by consecutive mutations (Fig. 2 right). One of them, H3, was clearly more abundant in the Meeting of Waters.

The population of Curimata that inhabit the Meeting of Waters exhibited significant pairwise $\phi_{\mathrm{ST}}$ values (significant genetic differentiation between population pairs) with 
Table 3 Indicators of demographic expansion

\begin{tabular}{|c|c|c|c|c|c|c|c|c|}
\hline & \multicolumn{4}{|c|}{ Curimata (Prochilodus nigricans) } & \multicolumn{4}{|c|}{ Tambaquí (Colossoma macropomum) } \\
\hline & $F_{\mathrm{s}}$ & $D$ & $r$ & $R_{2}$ & $F_{\mathrm{s}}$ & $D$ & $r$ & $R_{2}$ \\
\hline Upstream Blackwater & -0.39709 & -0.14690 & $0.15912 *$ & 0.1207 & 0.20067 & 0.00000 & 0.55556 & 0.4714 \\
\hline Upstrean Whitewater & 0.20373 & 0.23837 & $0.20817 *$ & 0.1698 & $-1.59357^{*}$ & 0.51516 & 0.07093 & 0.1687 \\
\hline Meeting of Waters & $-1.06131^{*}$ & $-1.15753^{*}$ & 0.71200 & 0.1960 & 1.21243 & 0.34074 & 0.38194 & 0.1468 \\
\hline Downstream & $-5.64098 * * *$ & $-1.44730 * *$ & 0.10302 & 0.0555 & $-3.39845^{* *}$ & 0.14808 & 0.04964 & 0.1264 \\
\hline
\end{tabular}

Non-significant raggedness values suggest population expansion. $R_{2}=$ Test $R_{2}$

$F_{\text {s }}$ Fu's test of selective neutrality, $D$ Tajima's test of selective neutrality, $r$ Raggedness Index

$* p<0.05$;* $p>0.01 ; * * * p<0.001$

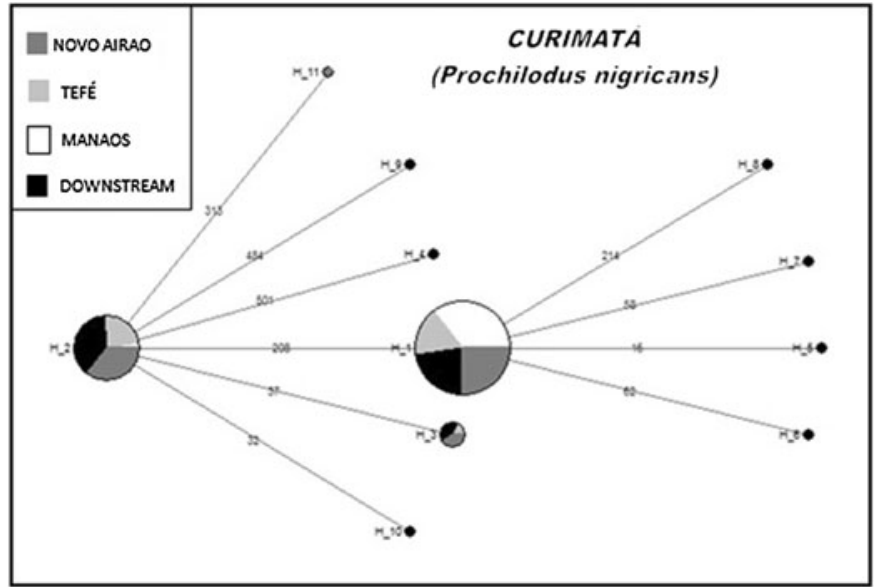

Fig. 2 Median-joining network showing the relationships among the Curimatá (Prochilodus nigricans) haplotypes (left) and the Tambaqui (Colossoma macropomum) haplotypes (right) defined by COI sequence variation. $\mathrm{H} \_1, \mathrm{H} \_2$, etc. are the haplotype names. Areas

all the other sampling points (Table 4). With the software Barrier, distance values higher than 0.1 were found between this sample and both blackwater and whitewater upstream areas (0.329 and 0.288 respectively). The number of migrants per generation $\left(N_{\mathrm{m}}\right.$, Fig. 3a) ranged between 0.001 (migration from downstream to the Meeting of Waters) and 96.29 (from the Meeting of Waters to downstream). Migration estimates between the uppermost and lowermost sampling points were higher downwards than upwards for the two species (respectively, 3.54 vs 2.72 for Whitewater and 0.058 vs 0.028 for Blackwater for Tambaqui; 94.33 vs 0.0004 for Whitewater and 96.3 vs 0.0005 for Blackwater for Curimata). However, migration was not linear. All migration values from the Meeting of Waters to other basin points were higher than one migrant per generation or OMPG (Mills and Allendorf 1996). In all the cases the migration was apparently asymmetric, being higher from the Meeting of Waters towards other basin points than in the opposite direction.

As for Curimatá, pairwise $\phi_{\mathrm{ST}}$ tests for genetic differentiation between Tambaqui samples provided significant

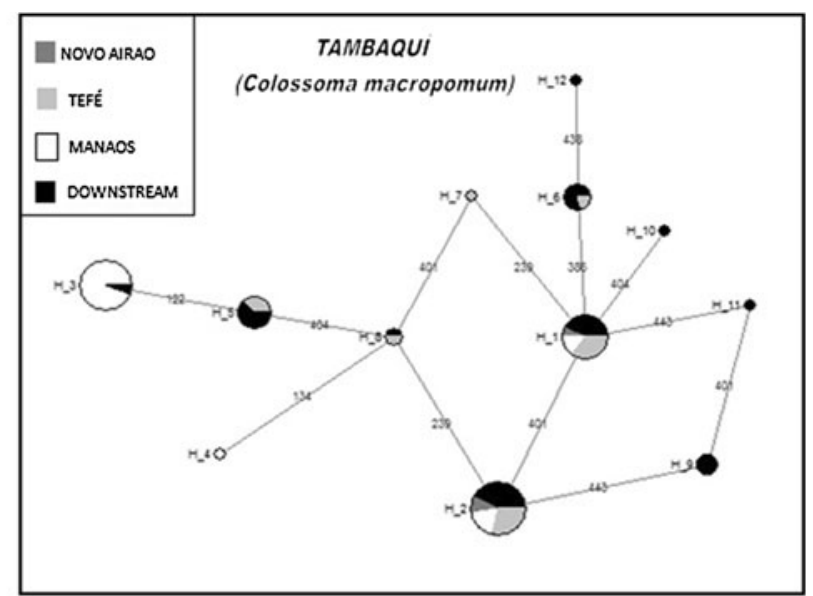

in circles are proportional to the frequency of each haplotype. Blackwater, Whitewater, Meeting of Waters and downstream samples are represented as dark gray, light gray, white and black respectively

$P$-values for all comparisons between the Meeting of Waters and the other sampling points (Table 4). The $>0.1$ barriers found in this species were located in the same points as in Curimatá, with values of 0.416 and 0.488 between the Meeting of Waters and blackwater and whitewater upstream samples respectively. $N_{\mathrm{m}}$ values were clearly asymmetric, more breeders per generation being generally exported from the Meeting of the Waters than immigrants imported with the exception of the small blackwater population (Fig. 3b).

\section{Discussion}

The results obtained in this study suggest a clear differentiation between the populations inhabiting the Meeting of Waters and the rest of the river Amazon for Tambaqui and Curimatá, two fish species of different behavior. Accordingly with their migratory capacity, the two species here analyzed exhibit shallow (Curimatá; Sivasundar et al. 2008) or null population structuring (tambaquí, which is a 
Table 4 Test for significance differentation between populations based on pairwise genetic distances $\left(\phi_{\mathrm{ST}}\right)$ with COI sequences for $P$. nigricans and C. macropomum

\begin{tabular}{lccc}
\hline & Novo Airao & Tefe & Manaus \\
\hline Curimata (P. nigricans) & & & \\
Novo Airao & - & - & \\
Tefe & -0.02494 & $0.15347 * * *$ & - \\
Manaus & $0.17621^{* * *}$ & -0.02254 & $0.19231^{* * *}$ \\
Downstream & -0.01790 & & - \\
Tambaqui $($ C. macropomum) & - & & \\
Novo Airao & -0.02451 & - & - \\
Tefe & $1.48792 *$ & $2.47304 * * *$ & $2.72917 * * *$ \\
Manaus & 1.25000 & 1.56985 & - \\
Downstream & & \\
\hline
\end{tabular}

$\phi_{\mathrm{ST}}$ levels of significance are indicated with one, two or three asterisks respectively: $* p<0.05 ; * * p<0.01$; *** $p<0.001$; without asterisk, non-significant

A

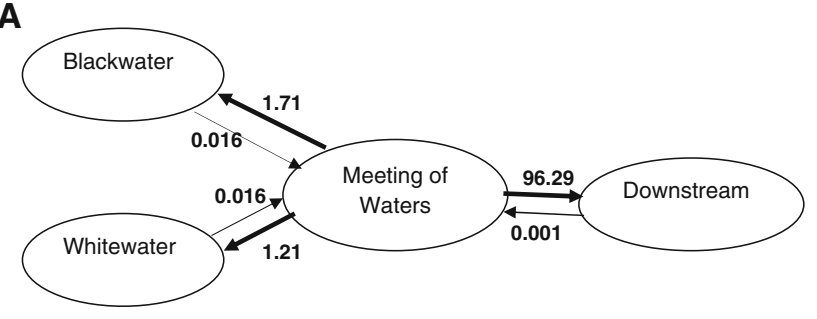

B

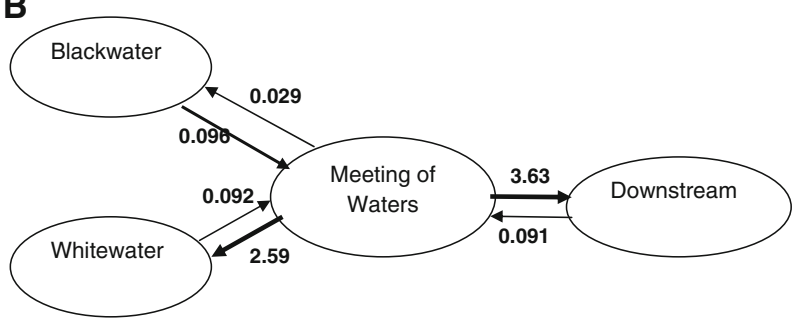

Fig. 3 Number of migrants per generation $\left(N_{\mathrm{m}}\right)$ between sampling points estimated with MIGRATE 3.2.16 software (Beerli and Palczewski 2010). a Curimatá Prochilodus nigricans; b Tambaqui Colossoma macropomum

panmictic population in the main river Amazon; Santos et al. 2007) in the whole drainage. Notwithstanding it, samples of the two species caught from that special area of the river Amazon exhibited less variation than those caught from other areas (Table 2), and were also significantly different, as shown by $\phi_{\mathrm{ST}}$ values (Table 4). These results highlight the particular features of the Meeting of Waters and point out a possible role of this zone as a shelter of genetic diversity of Amazonian fish populations.

Despite large geographical distances between some sampling locations, the barriers identified here and low migration rates from Blackwater and Whitewater reaches to downstream locations suggest that source-sink population models may partially explain our results. Asymmetric migration has been inferred from $N_{\mathrm{m}}$ estimates (Fig. 3). It suggests that the downstream population was formed by immigrants arriving from upstream areas (these joining in the Meeting of Waters), as logically expected for rivers and other dendritic ecosystems where there is maximum variation downstream (e.g. Horreo et al. 2011 and references therein). In this sense, high downstream diversity found in Santárem may also be explained by the river Tapajós, an important tributary in the low reach of the basin. New studies including this tributary could clarify the origin of the commented downstream diversity.

Dendritic population models have been described for other riverine fish species like for example the Amazonian Pirarucú Arapaima gigas (Hrbek et al. 2007), the guppy Poecilia reticulata (Barson et al. 2009) and the sculpin Cottus gobio (Hänfling and Weetman 2006). The model is explained via asymmetry in migration and genetic diversity; the tributary furthest downstream would normally represent a 'sink', receiving immigrants from rivers upstream in the drainage (Barson et al. 2009). In our results, however, we have found a crucial difference: upstream branches (Blackwater and Whitewater) also receive immigrants from the Meeting of Waters. This area is located in an intermediate position along the river, not upstream. This suggests that the system would be instable, since donors should be large enough for supporting continuous loss of emigrant breeders. Alternatively, it is possible that at least part of the upstream gene flow revealed here was an artifact due to reduced diversity in the Meeting of the Waters, may be caused by intense artisanal fisheries around Manaus (Batista and Petrere 2007).

The conclusion of this work is that, although both Curimatá and Tambaqui exhibit a shallow (if any) population structuring, the population of both species that inhabits the Meeting of Waters area exhibits significant 
genetic differentiation with all the other sampling points. Therefore, this area (near Manaus) could be considered as a shelter for evolutionary significant units (ESUs) for these valuable Amazonian fish. The points considered in the present study, though distant, allowed us to get a first idea of the status of genetic diversity throughout the Amazon basin, with main interest in the Meeting of the Waters. It is true that more extensive sampling, with more intermediate points, is needed for further studies. It would be interesting to sample different points within the Meeting of Waters area and further enough away from the intense fishing areas to delete the possible artifact due to intense fishing near Manaus.

\section{Insights for conservation}

From the results presented so far, the Meeting of the Waters could be recommended as a potential subject of special management, given its apparent role of shelter of fish ESU. Palsbøll et al. (2007) suggested that management unit status should be assigned when the observed estimate of genetic divergence is significantly greater than a predefined threshold value. However, in the present case there are not enough previous studies for establishing a threshold of genetic divergence that should be tailored specifically to each particular conservation context (Palsbøll et al. 2007). Considering together the evidence of genetic differentiation, reduced genetic variation and the special environmental conditions of the area, the Meeting of the Waters should be taken as a separate stock and managed as such.

The two species exhibit relatively reduced genetic diversity in the Meeting of the Waters (Table 2), indicating population isolation and/or reduced population size. It seems logical to reduce exploitation pressure on this zone, may be applying fisheries restriction. For Arapaima gigas, a highly valued Amazonian species with source-sink population model, it has been proposed to create a set of reserves to supply immigrants for locally depleted populations (Hrbek et al. 2007). Although such measure would not be very popular in the short-term because of the high economic value of the two considered species for local economy all along the basin (Gram et al. 2001; Dorea 2003; Batista and Petrere 2007), it would expected to be better accepted in Manaus (where these species are less important for the total catch; see Table 1) than in Santarem.

An alternative perspective for management of population networks with different degrees of isolation (as is the present case) was proposed by Tufto and Hindar (2003), who suggested that relatively higher harvesting thresholds may be acceptable for isolated populations. If Manaus receives lesser immigrants than any other population and therefore diversity is concentrated in other points of the network, such points would be more adequate targets for protection measures-if conserving diversity is the main objective. Protecting upstream areas and replicating high quality reserves, as proposed for Arapaima gigas (Hrbek et al. 2007), could be also recommended for Curimatá and Tambaqui in states where their fisheries are relatively less important for local economies. However, while reserves in the upper reaches in the Negro and Solimoes rivers would protect populations of both species in those locations, it is not clear that they will contribute to safeguard the whole genetic diversity in the river Amazon basin. In addition, the high diversity and unique alleles observed in downstream locations (Santarem) should be also considered of interest for conservation.

Given all the considerations above, a possible solution could be to manage each ecologically different area as a separate stock and try to conciliate the benefits of fisheries for local economies with the protection of the resource. Moderate catch restrictions in the Meeting of the Waters will also benefit protected species such as river dolphins (boto Inia geoffrensis and tucuxi Sotalia fluviatilis), which exhibit a clear preference for that area and suffer mortality by entanglement in gillnets there (Martin et al. 2004). Such moderate restrictions, combined with small or partial reserves localized in nearby areas, together with the valorization of local species (for example creating protected denominations of geographic origin or similar figures of quality product) and sustainable aquaculture, could contribute to balance conservation and fisheries of these two valuable species.

Acknowledgments We are grateful to Ivan G. Pola for help with laboratory tasks, and to Angel Rosales, Ione Ginuino, Gema Adan and Eduardo del Rosal for collaborating in sampling. Alba Ardura was economically supported by the Spanish National Project CGL200908279. This study was carried out in the context of the BrazilianSpanish cooperation project AECID D-023814-09.

\section{References}

Albert JS, Crampton WG (2010) The geography and ecology of diversification in neotropical freshwaters. Nat Educ Knowl 1(10): 13

Albert JS, Reis RE (2011) Historical biogeography of neotropical freshwater fishes. Berkeley, CA: University of California Press (in press)

Araújo-Lima CARM, Ruffino ML (2004) Migratory fishes of the Brazilian Amazon. In: Carolsfield, J, Harvey B, Ross C and Baer A (eds) Migratory fishes of South America. biology, fisheries, and conservation status. Co-published by World Fisheries Trust/ World Bank/IDRC, Victoria, pp 233-302

Bandelt HJ, Forster P, Röhl A (1999) Median-joining networks for inferring intraspecific phylogenies. Mol Biol Evol 16:37-48

Barson NJ, Cable J, Van Oosterhout C (2009) Population genetic analysis of microsatellite variation of guppies (Poecilia reticulata) in Trinidad and Tobago: evidence for a dynamic source- 
sink metapopulation structure, founder events and population bottlenecks. J Evol Biol 22(3):485-497

Batista V, Petrere Junior M (2007) Spatial and temporal distribution of fishing resources exploited by the Manaus fishing fleet, Amazonas, Brazil. Braz J Biol 67:651-656

Beerli P, Palczewski M (2010) Unified framework to evaluate panmixia and migration direction among multiple sampling locations. Genetics 185:313-326

Colonnello G (1991) Observaciones fenológicas y producción de hojarasca en un bosque inundable (Várzea) del Río Orinoco. Interciencia 16:202-208

Dorea JG (2003) Fish are central in the diet of Amazonian riparians: should we worry about their mercury concentrations? Environ Res 92:232-244

Estoup A, Largiader CR, Perrot E, Chourrout D (1996) Rapid one-tube DNA extraction for reliable PCR detection of fish polymorphic markers and transgenes. Mol Mar Biol Biotech 5:295-298

Excoffier L, Laval G, Schneider S (2005) Arlequin (version 3.0): an integrated software package for population genetics data analysis. Evol Bioinform Online 1:47-50

Farias IP, Torrico JP, Garcia-Davila C, Santos MCF, Hrbek T, Renno J-F (2010) Are rapids a barrier for floodplain fishes of the Amazon Basin? A demographic study of the keystone floodplain species Colossoma macropomum (Teleostei: Characiformes). Mol Phyl Evol 56:1129-1135

Fu Y-X (1997) Statistical tests of neutrality of mutations against population growth, hitchhiking and background selection. Genetics 147:915-925

Gram S, Kvist LP, Caseres A (2001) The economic importance of products extracted from amazonian flood plain forests. Ambio 30:365-368

Hall TA (1999) BioEdit: a user-friendly biological sequence alignment editor and analysis program for Windows 95/98/NT. Nucleic Acids Sympos Ser 41:95-98

Hänfling B, Weetman D (2006) Concordant genetic estimators of migration reveal anthropogenically enhanced source-sink population structure in the river sculpin. Cottus gobio. Genetics 173(3): 1487-1501

Harpending H (1994) Signature of ancient population growth in a low-resolution mitochondrial DNA mismatch distribution. Hum Biol 66:591-600

Horreo JL (2012) "Representative genes", is it OK the use a small amount of data to obtain a phylogeny that is at least close to the true tree? J Evol Biol. doi:10.1111/j.1420-9101.2012.02622.x

Horreo JL, Martinez JL, Ayllon F, Pola IG, Monteoliva JA, Héland M, Garcia-Vazquez E (2011) Impact of habitat fragmentation on the genetics of populations in dendritic landscapes. Fresh Biol 56:2567-2579

Hrbek T, Crossa M, Farias IP (2007) Conservation strategies for Arapaima gigas (Schinz, 1822) and the Amazonian várzea ecosystem. Braz J Biol 67(4):909-917

Hughes JM, Schmidt DJ, Finn DS (2009) Genes instreams: using DNA to understand the movement of freshwater fauna and their riverine habitat. Bioscience 59(7):573-583

Kinlan BP, Gaines DD (2003) Propagule dispersal in marine and terrestrial communities: a community perspective. Ecol 84: 2007-2020

Manni F, Guerard E, Heyer E (2004) Geographic patterns of (genetic, morphologic, linguistic) variation: how barriers can be detected by using Monmonier's algorithm. Hum Biol 76(2):173-190
Martin AR, Da Silva VMF, Salmon DL (2004) Riverine habitat preferences of botos (Inia geoffrensis) and tucuxis (Sotalia fluviatilis) in the Central Amazon. Mar Mamm Sci 20(2):189-200

Mills LS, Allendorf FW (1996) The one-migrant-per-generation rule in conservation and management. Conserv Biol 10(6):1509-1518

Monmonier M (1973) Maximum-difference barriers: an alternative numerical regionalization method. Geog Anal 3:245-261

Moritz C (1994) Defining "evolutionary significant units" for conservation. Trends Ecol Evol 9(10):373-375

Palsbøll PJ, Bérubé M, Allendorf FW (2007) Identification of management units using population genetic data. Trends Ecol Evol 22(1):11-16

Quintero-Pinto LG (2003) Especies ícticas amazónicas promisorias para la acuicultura nacional En: Colombia Evento: IV Seminario Internacional de Acuicultura y I congreso de investigaciones acuícolas

Ramos-Onsins SE, Rozas J (2002) Statistical properties of new neutrality tests against population growth. Mol Biol Evol 19:2092-2100

Reeves GH, Benda LE, Burnett KM, Bisson PA, Sedell JR (1995) A disturbance-based ecosystem approach to maintaining and restoring freshwater habitat of evolutionary significant units of anadromous salmonids in the Pacific Northwest. Am Fish S S 17:334-349

Santos MCF, Ruffino ML, Farias IP (2007) High levels of genetic variability and panmixia of the tambaqui, Colossoma macropomum (Cuvier, 1816) in the main channel of the Amazon River. J Fish Biol 71:33-44

Schmidt GW (1976) Primary production of phytoplankton in three types of Amazonian waters. IV. On the primary productivity of phytoplankton in a bay of the lower Rio Negro (Amazonas, Brazil). Amazoniana 5:517-528

Silva EA, Sterwart DJ (2006) Age structure, growth and survival rates of the commercial fish Prochilodus nigricans (bocachico) in North-eastern Ecuador. Environ Biol Fish 77:63-77

Sivasundar A, Bermingham E, Orti G (2008) Population structure and biogeography of migratory freshwater fishes (Prochilodus: characiformes) in major South American rivers. Mol Ecol 10: 407-417

Tajima F (1989) The effect of change in population size on DNA polymorphism. Genetics 123(3):597-601

Thompson JD, Higgins DG, Gibson TJ (1994) Clustal-W, improving the sensitive of progressive multiple sequence alignment through sequence weighting, position-specific gap penalties and weight matrix choice. Nucl Acid Res 22:4673-4680

Tufto J, Hindar K (2003) Effective size in management and conservation of subdivided populations. J Theor Biol 222(3):273-281

Waples RS (1995) Evolutionarily significant units and the conservation of biological diversity under the endangered species act. Am Fish Soc Symp 17:8-27

Ward RD, Zemlak TS, Innes BH, Last PD, Hebert PDN (2005) DNA Barcoding Australia's fish species. Proc Roy Soc B Biol 360: 1847-1857

Ziburski A (1990) Ausbreitungs-und Reproduktionsbiologie einiger Baumarten der amazoniaschen Uberschwemmungs-walder. Ph.D. Thesis, University of Hamburg, Hamburg. 112 pp 